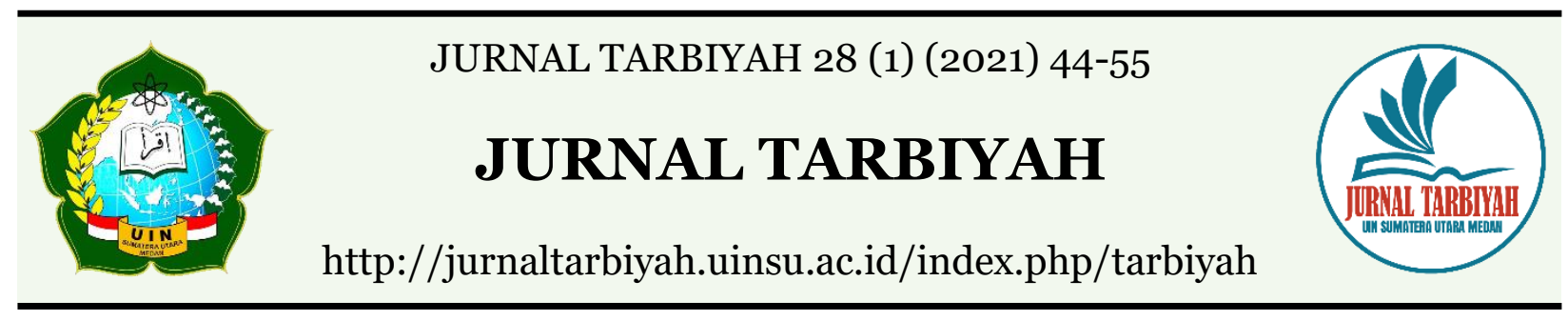

\title{
LEXICAL MEANING OF "PAKKAT" YOUNG ROTTAN PLANT IN MANDAILING SOCIETY IN PADANG LAWAS DISTRICT: ECOLINGUISTICS STUDY
}

\author{
Ernita Daulay ${ }^{1}$ Dwi Widayati² \\ ${ }^{1}$ State Islamic University of North Sumatera, Medan, Indonesia \\ 2 University of North Sumatra, Medan, Indonesia \\ Email: ${ }^{1}$ ernitadaulay@uinsu.ac.id, ${ }^{2}$ dwiwidayati@usu.ac.id
}

DOI : 10.30829/tar.v28i1.971

Accepted: March 25th, 2021. Approved: June 28th, 2021. Published: June 30th, 2021

\begin{abstract}
Pakkat is a rattan tuber that is still very young and tastes a bit bitter. Young Rottan plants known as "Pakkat" growing in the wilderness are consumed as fresh vegetables or food additives eaten with rice is a traditional food. Mandailing. This study used data that was analyzed descriptively qualitatively using ethnographic methods which aimed to describe completely and thoroughly the young rattan plant "Pakkat" in the Mandailing community in Matondang village, using the approach of observation and interviews with the local community. In the process of collecting field data, the researcher met several informants who knew about Pakkat knowledge. In conducting this research, the authors obtained field data that Pakkat is a typical Mandailing food which is widely believed that those who eat Pakkat will have a high appetite. In addition, Pakkat can also help reduce various types of risks such as heart disease, gout, colds, diarrhea, sugar.
\end{abstract}

Keywords: Pakkat, Mandailing Society, Ecolinguistics study 


\section{INTRODUCTION}

Ecolinguistics studies have parameters, including interrelationships (language and environment interrelation), environment (physical and socio-cultural environment) and diversity (language and environmental diversity). Interdisciplinary studies linking ecology and linguistics began in the 1970s when Einar Haugen (1972) created the paradigm of "Language ecology, he argues that language ecology is metaphorical, namely the relationship between language and the environment is limited to a lexicon set. Language lives in the minds of humans and the language community, real life in use between speakers in society. So there is a psychological environment (psychiatric) and a social environment. Ecology is used as a basic science in understanding interactions in the environment, it can be concluded that Ecology is a branch of a scientific discipline biology regarding the interaction between things with other living things and also with the surrounding environment. Until a new theory was born by Halliday (1990) and used the concept of ecology in a non-metaphorical sense, namely ecology as a biological environment and he criticized how language systems affect user behavior in managing the environment.

Although studies on the interrelation of language and its environment have emerged since the 1970s, theoretical approaches and analytical models in ecolinguistic studies were only formulated in the 1990s. Bang and Door's (2000) Ecolinguistic Dialectical Theory argues that "language is understood as a social practice or the embodiment of human social activity in society". In other words, language only exists, lives and functions if there is social praxis. Without social praxis there can be no language (which is really alive), although social praxis can occur without language. The three important dimensions of language in social practice according to Bang and Dorr (2000) are as follows (1) ideological dimensions, namely dimensions related to the overall mental content of individuals and collectives, cognitive aspects (knowledge-awareness), organizing ideology and life guides, livelihood, and life, and the psychic system. (2) the sociological dimension is a sociological dimension related to patterns or the way we organize and combine interrelations in order to care for togetherness and harmony between individuals, and social, which is the strength and love for one another in various levels and living spaces, or is it the other way around not knowing each other. and befriending, even with the neighbors who are next to us (also in intra-family life which is "Close, butFar, Far, but Near"), (3) Biological dimensions provide understanding and awareness of biological collectivity and our coexistence with other species (animals, 
animals, plants, land (and land), water, sea (-an), microorganisms and so on, both with Gaia and without Gaiya (Theory of Planet Earth as a life.

Syarif (2008) states that ecologically, the life of coastal communities has a different way of life because their life is basically dependent on two environments of land and sea, rivers, water from the marine aspect looking for fish as a daily necessity; every community also has customs that different. Mbete (2013:5) argues that environmental language is a linguistic corpus which (content) describes the environment, both macro natural environment and human environment (with culture) micro. In prehistoric times humans were still familiar with hunting and gathering in order to meet the needs of their own bodies, because at that time humans still used the environment to meet their food needs. Humans are still living on the move - moving (Nomadic) from one place to another where they think they have an adequate food supply. Along with the development of human civilization, humans began to evolve from hunting and gathering to farming. Indonesia is the largest rattan producing country in the world. It is estimated that $80 \%$ of rattan raw materials worldwide are produced by Indonesia, the rest is produced by other countries such as the Philippines, Vietnam and other Asian countries. Every human things need food, where the function of that food can affect their body. In addition to influencing food, it can also provide a sense of knowledge, cultural value, artistic value, symbols, and local wisdom of an ethnic group which made it popular and has developed a lot today. Any nutrition, currently food has developed into a lifestyle for the community. A side from being a lifestyle, food is now becoming a national identity, especially Pakkat. Pakkat is known as food that comes from the Mandailing tribe and most of those who consume it are adults, and its presence is very difficult to find on weekdays. Based on the proverbial dictionary book written by JS Badudu, the meaning of the word "rattan" in the above proverb is interpreted as a plant that has good use and quality. The fact is the same as the meaning in the proverb, that rattan is indeed a high quality plant that is widely used by the community, especially as a raw material in the furniture and handicraft industries. Rottan is a vine from the Palmae family. The name of this plant actually comes from the Malay language, namely "raut" which means to peel, peel, or smooth. Especially as raw materials in the furniture and handicraft industry. Rattan is a vine from the Palmae family. The name of this plant actually comes from the Malay language, namely "raut" which means to peel, peel, or smooth. The development of the food processing product industry today makes food no longer a mere necessity in order to survive, but the function of food now varies from as a basic need, there are also elements of psychological, health, 
knowledge, belief, and belief in determining food. Young rattan plants known as "pakkat" grown in the wilderness are consumed as fresh vegetables or food additives eaten with rice and it is a typical traditional food Mandailing. Pakkat is usually crowded during the Ramadan month's as a menu of fresh vegetables when it opens. Pakkat will taste a little chewy and bitter on the tongue, that's what makes many people addicted and can be enjoyed with soy sauce, lime, onions and ground chilies. Usually, to process Pakkat, young rattan is first burned over charcoal for about 15 minutes or until the young rattan is soft. Then, the outer skin is peeled off with a knife and the white rattan meat is usually cut into pieces about $10 \mathrm{~cm}$ in size and ready to be served. This Pakkat can be consumed by boiling it is useful for eliminating the bitter taste, especially served with the typical Batak onion sauce (Harrist, 2014).

Rottan is not only used as raw material for the furniture industry but also as food and medicine. Many types of rattan produce rattan shoots or edible rattan hearts such as Calamus hookerianus, Calamus metzianus, and Calamus thwaitesii (Reunika, 2007). According to Herbarium Medanense (2015), the classification of pakkat (name of rattan in the Padang lawas and south Tapanuli areas) is as follows: Kingdom: Plantae Division: Spermatophyta Class: Monocotyledoneae Order: Aracales Family: Arecaceae Genus: Calamus Species: Calamus caesiusBlume (Garden Rattan). Rattan cultivation must be in natural conditions. This plant initially grows creeping up on the soil surface and then develops by climbing and wrapping around tree trunks. The stems of this plant grow upright until they reach a height of about 2 to 2.5 meters. After reaching that height, the rattan stems will curve so that they resemble bamboo plants, the rattan stems are segmented with sizes between 15-30 $\mathrm{cm}$ and have a diameter of $2-8 \mathrm{~cm}$. Pakkat "Umbut Rattan" is a typical food made from rattan stalks, but not all rattan stalks can be used, only young rattan shoots are used and at a young age where the rattan stems are generally green so that they can be harvested into Pakkat.

The stems of the Rottan plant are protected by thorny midrib-shaped attributes which are quite difficult for farmers and can injure if they are not careful. Most of the farmers cultivate the stems of rattan as a result of harvest by turning yellow in line with the increasing maturity of this plant. Rattan farmers usually carry a machete $60 \mathrm{~cm}$ long as a tool to cut down, clean thorns, and peel the rattan so that the stems can be taken. Rottan species diversity is a measure that states the variety of plant species from a community which is influenced by the number and abundance of each species. Protected forest is forest that is managed with the main objective of controlling the danger of 
flooding, preventing erosion, as well as protecting wild animals and their environment and peeling the rattan so that the stems can be removed. Rottan species diversity is a measure that states the variety of plant species from a community which is influenced by the number and abundance of each species. Protected forest is forest that is managed with the main objective of controlling the danger of flooding, preventing erosion, as well as protecting wild animals and their environment and peeling the rattan so that the stems can be removed. Rattan species diversity is a measure that states the variety of plant species from a community which is influenced by the number and abundance of each species. Protected forest is forest that is managed with the main objective of controlling the danger of flooding, preventing erosion, as well as protecting wild animals and their environment.

\section{LITERATURE REVIEW}

Ecolinguistics existed since the 1970 s when Haugen (1972) proposed a theoretical conceptual framework with a number of linguists, compiled in The Ecology of Language. Haugen in Fill and Muhlhausler (2001:57) states that language ecology is the study of existing inter-language interactions with the environment. Understanding the environment in ecolinguistics leads to the opinion that the physical and social environment. The physical environment involves physical geography: the topography of a country (coastal, valley, land, highland, mountain) climate, and intensity of rainfall, the economic basis of human life comprising fauna, flora and mineral resources; While the social environment consists of the various forces of society that make up the minds and lives of every individual among them: religion, ethics, forms of political organization, and art.

Fill and Mushausler (2001:11) argue that ecolinguistics is applied linguistics that is cross-cutting (interdisciplinary). It explains that ecolinguistics as a broader study of its scope in studying syntax, semantics, and pragmatics, and hence the need for some innovative new theory to investigate these ideas empirically. Then, Crystal (2008:161162) states that ecolinguistics is a study that reflects the nature of ecology in biological studies, in which the interaction between language and cultural environment is seen as the core. It means that ecolinguistics is also called as the language ecology, linguistic ecology and sometimes as green linguistics.

Alexander and Stibbe (2010) define ecolinguistics as a study of the impact of language use in survival that bridges relationships between humans, other organisms, 
and the physical environment that is normatively oriented towards the preservation of sustainable relationships and life. It means that ecolinguistics is closely related to how language serves to mold, nurture, influence or destroy relationships between people, living conditions, and the environment. Stibbe (2010:1) asserts that ecolinguistics evolved as a result of human ecological development associated with various systems (economic, social, religious, cultural, linguistic, and ecosystem systems) that are interdependent and related to one another.

Based on the information previously, it is concluded that the study of ecolinguistics has parameters between language and environment. Sapir in Fill and Muhlhausler (2001:2) states that within the scope of ecolinguistics, language and environmental relations exist only on the level of the lexicon, not, for example, at the phonological or morphological level of this interrelation exists merely on the level of the vocabulary and Notes, for example, on that of phonology or morphology (Bang and Door, 1996:47). It means that an ecolinguistic study, living and used languages illustrate, represent, symbolically-verbal representation in the environment, both the social environment and the socio-cultural environment. Language changes as the social and environmental changes change (Liebert: 2001). This statement also is added by Mbete (2009:7) states that '... language change ... represents ecological changes'. The process of change in the language runs in stages for a long time, unknowingly by its speakers, and is inevitable. Furthermore, ecolinguistics' has been used to describe studies of language interaction and diversity; studies of texts such as signposts which are outdoors; analysis of texts which happen to be about the environment; studies of how words in a language relate to objects in the local environment; studies of the mix of languages surrounding pupils in multicultural schools; studies of dialects in particular geographical locations, and many other diverse areas. The multiplicity of approaches arises from different understandings of the concept of 'ecology', from a very broad concept of the interaction of some things with other things' to narrow concepts such as 'related to environmentalism'. Steffensen and Fill (2014: 7) identify four different interpretations of ecology that lie behind the different approaches. They are:

1. Existing in a symbolic ecology, where different languages interact with each other in a given location.

2. Part of a sociocultural ecology where it shapes societies and cultures.

3. Concerning with cognitive ecology and how the cognitive capacity of organisms affects how they adapt to their environment. 
4. There is a natural ecology which is concerned with the relationship of language to its biological and physical environment.

From the explanation in previously, it can be inferred that ecolinguistics or language ecology is an approach in the study a language related to ecological and environmental problems pioneered. Fill (2017) states that this theory is a new trend in linguistic research to facilitate not only social factor but also ecological context in a society, because we live in the world and it has a role in shaping the world through the language it is used.

\section{RESEARH METHOD}

The study of ecolinguistic as an interdisciplinary science connects a linguistic theory with a dialectical theory of social praxis known as "The three dimensionality of praxis." The theory of three dimensions of social praxis is a theory that is applied in observing the environment and environmental issues to explain about environmental language norms presented in the form of a theoretical framework. This study uses the ecolinguistic theory proposed by Jorgen Chr Bang and Jorgen Door (1993). Methodology comes from the words method and logos. Method means the right way to do something; logos means science.

According to Sudaryanto (1982: 2), "Methodology is a way of doing something by using the mind carefully to achieve a goal". Research is an activity to find, record, formulate, and analyze data to compile research results. So, the research method is the science of the path to reach an understanding. Researchers used in-depth interviews with informants. Moleong (2017: 186) describes an interview as a conversation with a specific purpose. The conversation was carried out by two parties, namely the interviewer (interviewer) who asked the question and the interviewer who gave the answer to the question to extract all information from the informant using note-taking and recording techniques to record and record the informant's conversation which contained information in the form of vocabulary which was the result of the data are required. The research method is the science of the path to reach an understanding and researchers used in-depth interviews with informants. The research method used in the research is ethnographic qualitative method, which is a written work based on in-depth fieldwork conducted in an ecolinguistic study.

According to Sugiyono (2015: 35) qualitative methods are used to understand the meaning behind the visible data. The data in this study are objects contained in Pakkat 
"Rottan Muda" which are a form of visible data which are then analyzed. The data source is obtained from the speaking community. The technique used to collect data is in the form of interviews. The analysis then produces a description of the meaning of young rottan found in the village of Matondang, Kab. Padang Lawas. Interviews were conducted with informants who are indigenous to Matondang village to obtain information about the lexical meanings of the "young rottan" pakkat. Moleong (2017: 186) describes an interview as a conversation with a specific purpose. The conversation was carried out by two parties, namely the interviewer (interviewer) who asked the question and the interviewer who gave the answer to the question to extract all information from the informant using note-taking and recording techniques to record and record the informant's conversation which contained information in the form of vocabulary which was the result of the data are required. The research method is the science of the path to reach an understanding. Researchers used in-depth interviews with informants. Moleong (2017: 186) describes an interview as a conversation with a specific purpose. The conversation was carried out by two parties, namely the interviewer (interviewer) who asked the question and the interviewer who gave the answer to the question to extract all information from the informant using note-taking and recording techniques to record and record the informant's conversation which contained information in the form of vocabulary which was the result of the data are required and described the interview as a conversation with a specific purpose. The conversation was carried out by two parties, namely the interviewer (interviewer) who asked the question and the interviewer who gave the answer to the question to extract all information from the informant using notetaking and recording techniques to record and record the informant's conversation which contained information in the form of vocabulary which was the result of the data are required and described the interview as a conversation with a specific purpose. The conversation was carried out by two parties, namely the interviewer (interviewer) who asked the question and the interviewer who gave the answer to the question to extract all information from the informant using note-taking and recording techniques to record and record the informant's conversation which contained information in the form of vocabulary which was the result of the data are required.

This study aims to determine how the cultivation and meaning of "Pakkat" rattan in a protected forest area in Matondang Village, Ulu Barumun District - Kabubaten Padang Lawas which has a major function and role for the survival of the community. 
Based on the Tellu expert (2005) states that the grouping of rattan types is generally based on the similarity of the morphological characteristics of plant organs, namely: roots, stems, leaves, flowers, fruit and additional tools. Rattan is a plant with segmented stems that live creeping or climbing on other plants, rattan can grow well in tropical and subtropical climates. Indonesia is a comfortable place for him to grow. Pakkat or young rattan sticks are a favorite food of the Mandailing tribe because they are very special; usually people who eat them will be addicted. Pakkat is usually cut $60 \mathrm{~cm}$ long, Pakkat is taken from rattan shoots about one meter long which are burned over coals of coconut shell or charcoal which are burned in a barrel for about 15 minutes or until the shoots soften until the rattan skin is peeled off with a knife, the pakkat can also be boiled or rolled. White rattan meat called pakkat. Pakkat is ready to eat as fresh vegetables or as a complement to holat fish soup and becomes a unique food, for example, the rattan is burned first, then the soft part is removed and so on, the soft tubers are cut into pieces, usually served with a special chili sauce whose main ingredient is Mandailing watery soy sauce, in other words it can also be processed with coconut milk curry such as cooking bamboo shoots (young bamboo shoots), pakkat has properties to increase appetite. The taste is a bit bitter. The stems of rattan are the most important part because the economic value of rattan lies in the stems, where the rattan stems are elongated and round like cylinders or triangles, the stems of the rattan plant are divided into sections, each bounded by books. The rattan fronds and leaf stalks are attached to the books, the rattan jam stalks grow upward towards the sun, the ends of the rattan stems will always get longer (Januminro, 2000).

The leaves of the rattan plant are compound-leaved and have leaf midribs that sit on a book and cover the surface of the stem segment. Leaflets grow on the midrib. The location of the leaves is parallel or even pinned or odd or alternate along the leaf midrib. Rattan leaves are covered with thorns of various shapes and colors (Januminro, 2000).

Flowers Rattan is a compound flowering plant which is divided into two groups, namely the type of rattan that flowers on the edge of the stem, which produces more than one flower, and the type of rattan that flowers at the end (terminal) which only appears once during its life and after the last generative process of the plant. die. Rattan flowers are wrapped in a spata, usually male and female flowers are monoceous, but some are diaceous. The size of the flower is relatively small, the color of the rattan flower varies, and the rattan fruit consists of an outer skin in the form of trapezoidal scales and is arranged vertically and is fruit toxic. The size of the scales varies, depending on the size 
of the fruit, the bigger the size of the fruit, the bigger the size of the scales, the shape of the rattan fruit surface is smooth or rough, hairy.has the following meanings: an appetite enhancer, eliminates thirst, eliminates angina, cures ulcers, as a medicine for malaria and cleanses the kidneys. According to the community, Pakkat, which is food from the forest that can be consumed and utilized, the forest as the environment must be preserved as a source of community life, in this case the local community builds an organization for the environmental movement that actively encourages efforts to save the environment in Matondang village because the use of forests as a source of food definitely requires assistance from many parties. Communities around the forest will begin to open up areas outside the forest and improve their quality of life. Collectors of material from the forest, processing these materials into food and distributing final food products can make this activity a source of economic income which is expected to lead to food security for the people of Matondang village in the next generation.

Based on the information obtained, there are several uniqueness of rattan plants, including when the stems are cut, they will release water. This technique is commonly used by adventurers / explorers to survive in the wild. In addition, some rattan extracts resin (resin) from the flower stalks. This sap is red in color and is known in the trade as 'dragon's blood' or dragon's blood. Generally, resin is used to color guitars or violins. Based on the information obtained, there are several uniqueness of rattan plants, including when the stems are cut, they will release water. This technique is commonly used by adventurers / explorers to survive in the wild. In addition, some rattan extracts resin (resin) from the flower stalks. This sap is red in color and is known in the trade as 'dragon's blood' or dragon's blood. Generally, resin is used to color guitars or violins. Based on the information obtained, there are several uniqueness of rattan plants, including when the stems are cut, they will release water. This technique is commonly used by adventurers / explorers to survive in the wild. In addition, some rattan extracts resin (resin) from the flower stalks. This sap is red in color and is known in the trade as 'dragon's blood' or dragon's blood. Generally, resin is used to color guitars or violins.

\section{CONCLUSION}

Pakkat is obtained from rattan shoots approximately one meter long which are burned over coals of coconut shell or charcoal which are burned in a barrel for about 15 minutes or until the shoots soften and then peel the rattan skin with a white rattan meat knife inside which is called pakkat. The rattan shoots are long like rattan and then grilled 
with hot coals so that they become soft after which the skin is peeled off and the flesh is white to eat. Pakkat is a unique food obtained from young rattan stalks and is no stranger to being a typical food during the month of Ramadan. The districts of Padang Lawas and Tapsel "pakkat" are very easy to find. These small pieces of pakkat are commonly served with soy sauce which is only mixed with shallot slices, ground red chilies and lime. the taste is very fitting when eating it together with grilled fish. Pakkat is commonly sold during the month of Ramadan and is used as an iftar dish that can be processed into a variety of dishes, ranging from fresh vegetables, eaten with ointment, or curried with typical Mandailing spices. It turns out that a lot of food from the forest can be consumed and utilized. With materials sourced from forests that are still quite extensive in Indonesia, it is hoped that the community will not lack food sources that can be processed in various ways, tastes and attractive displays. Even relatively easy and simple ways to process can be done, such as the pakkat. Rattan is currently widely cultivated because it has many benefits and is used as a source of livelihood and absorbs labor. Utilization of rattan rods in North Sumatra includes as a woven material (scorching sun protection installed in the ventilation of homes and offices), crafts, furniture frames, straps, and household furniture such as furniture, chairs, tables, shelves, room dividers, beds. , and wardrobes. In addition, other parts such as fruit, sap, and roots are used for vegetables, cooking spices, traditional medicine, and raw materials for coloring the ceramic industry.

In this research that can be given in this research are as follows:

1. PIt is important to pay attention to and be supported, including the attention of the government, including in terms of providing a market for pakkat produced by farmers because it can increase local income naturally.

2. Utilization of the forest as a food source definitely requires assistance from many parties. It is necessary to hold UKM ((Small and Medium Enterprises) because the community around the forest will begin to open up areas outside the forest and improve their quality of life. Collecting materials from forests, processing these materials into food and distributing final food products can make this activity a source of economic income which is expected to lead to food security for the Indonesian people. 


\section{REFERENCES}

Badudu, JS (1996). This is the Correct Indonesian Language I. Jakarta: Gramedia Pustaka Utama

Bang, J. Chr. and Door, J. (1993). EcoLinguistics: A Framework. site:www.jcbang.dk/main/ecolinguistics/Ecoling_AFramework1993.pdf

Cut Nuraini. Mandailing Batak Tribe Settlements. Gadjah Mada University Press. Yoghakarta 2004

Husein, R. 2016. Tannin test on rattan types found in Aek-Nauli Parapat Forest Simalungun Regency, North Sumatra. Thesis Biology Study Program. Faculty Mathematics and Natural Sciences, UNIMED. Field.

Januminro, CFM. 2000. Indonesian Rattan Potential of Standard Management Collection Cultivation Quality and Business Prospects. Kansius. Yogyakarta.

Journal of forestry studies by Hafnita Wirawati Harahap, Financial analysis and marketing Pakkat in Simangambat sub-district, Padang Lawas Utara district Marwati. (2000). Indonesian Cuisine Knowledge. Adi Cita Karya Nusa

Mbete, Aron Meko. 2013. A Brief Guide to Writing Ecolinguistic Research Proposals. Denpasar: Vidia.

Moleong, Lexy J. 2017. Qualitative Research Methodology (Revised Edition). Bandung: Rosdakarya.

Meiksyana Raynold Renjaan. 2014. Kei Lexicon in the Marine Environment: Study Ecolinguistics. Thesis. Graduate School of Udayana University - Denpasar Pribadi H, 2012. Economic Study of Rattan Furniture Industry Business Development in Palu City Central Sulawesi Province. Tropical Forest Journal (13) 2. 